Crop Breeding and Applied Biotechnology 12: 269-276, 2012

Brazilian Society of Plant Breeding. Printed in Brazil

\title{
ARTICLE
}

\section{Inbreeding depression in castor bean (Ricinus communis L.) progenies}

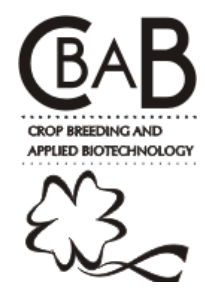

\author{
Inocencio Junior de Oliveira ${ }^{*}$, Maurício Dutra Zanotto ${ }^{2},{\text { Milton } \text { Krieger }^{3} \text { and Roland Vencovsky }}^{4}$
}

Received 24 May 2011

Accepted 04 July 2012

\begin{abstract}
The purpose of this study was to investigate inbreeding depression (DE) in castor bean. From a population derived from the Guarani cultivar, 60 mother plants were sampled. Three types of progenies were obtained from each one: from self-pollination $(A U)$, from crosses (CR) and from open pollination (PL). Grain yield of the progenies was evaluated in two locations. There was a strong interaction of progenies $x$ locations, which led to obtaining estimates within each location. Broad variation was observed in inbreeding depression, with mean values of $6.7 \%$ and $13.4 \%$, comparing AU progenies with PL progenies. It was observed that the population has high potential for selecting promising inbred lines. The frequency of mother plants generating progenies with simultaneous high general combination capacity and low inbreeding depression was low. Recurrent selection will increase the occurrence of parent plants associating these two properties, which is necessary for obtaining superior synthetic varieties.
\end{abstract}

Key words: Castor bean, inbreeding depression, synthetic varieties, $G \times$ E interaction.

\section{INTRODUCTION}

Castor bean is an oil crop with high socio-economic value and a source of foreign exchange credits for the country. Its products and sub-products are used in industry and in agriculture, as well as presenting perspectives for use as an energy source in the form of biodiesel (Costa et al. 2006).

Due to interest in castor bean growing, it is important to undertake plant science and genetic studies for development of productive genotypes adapted to crop regions, as well as to investigate the genotype $\mathrm{x}$ environment interaction.

In castor bean, the number of cultivars available is still quite reduced. That way, breeding programs that develop varieties and hybrids must be encouraged. The most frequently used method for obtaining homozygous inbred lines is artificial self-pollination to obtain uniformity, with the major consequence being depression through inbreeding (Scapim et al. 2006). Depression, strictly speaking, is a reduction in expression of quantitative traits as a result of the increase of homozygosity caused by inbreeding.

Inbreeding depression is associated with the presence of deleterious and lethal alleles in homozygous genotypes. Many recessive alleles remain hidden under heterozygous conditions in panmictic populations. As homozygosity increases in inbred populations, there is greater probability of manifestation of recessive characteristics, many of which are deleterious, resulting in loss of vigor (Godoy et al. 2005). Nevertheless, species with mixed reproduction systems should present less loss of vigor with inbreeding (Bertini et al. 2001).

Castor bean presents a mixed system of sexual reproduction such that most of the cultivars consist of open pollination populations. A mixed population is that which presents a mean rate of crosses from $5 \%$ to $95 \%$. These values are a populational mean and may vary from one individual to another.

In the castor bean crop, information is lacking in regard to the genetic structure of many traits and their type of genetic inheritance. Studies regarding depression through inbreeding in castor bean were not found.

One of the purposes of castor bean genetic breeding programs in the long term is obtaining hybrids of inbred lines to exploit heterosis. Govindan et al. (1999) and Manivel et al. (1999) observed the possibility of exploiting heterosis

\footnotetext{
${ }^{1}$ Embrapa Amazônia Ocidental, Rodovia AM - 010, km 29, Zona Rural, 69.010-970, Manaus, AM, Brazil. *E-mail: inocencio.junior@cpaa.embrapa.br

${ }^{2}$ Faculdade de Ciências Agronômicas, UNESP - Câmpus de Botucatu, Fazenda Experimental Lageado, 18.603-970, Botucatu, SP, Brazil

3 In memorian

${ }^{4}$ Escola Superior de Agricultura Luiz de Queiroz, USP, Av. Pádua Dias, 11, 13.418-900, Piracicaba, SP, Brazil
} 
in castor bean. Obtaining homozygous lines by means of self-pollination should lead to inbreeding depression in grain production. Thus, the value of a population as a source of inbred lines is dependent on inbreeding depression in relation to various characteristics, mainly grain yield, which limits obtaining good inbred lines to later obtainvigorous hybrids (Simon et al. 2004).

In regard to development of hybrid castor bean seeds, there is still little interest in Brazil due to the low technological level used in growing of castor beans by producers of this oil crop. In the states of Mato Grosso and Goias, four commercial hybrids have been grown as a "safrinha" (second crop), following soybeans or corn (Savy Filho2005). In countries with more developed agricultural activity, like the United States, the use of commercial hybrids is very frequent (Freire et al. 2001).

For the purpose of studying these questions which are fundamental for genetic breeding of the crop on scientific foundations, progenies with different levels of inbreeding obtained by crosses, self-pollination and open pollination were obtained and evaluated in this study. The genetic study of these progenies, with emphasis on quantitative genetics should bring useful information with a view toward future breeding programs, as well as being interesting from the point of view of basic genetics.

\section{MATERIALS AND METHODS}

Due to increasing interest in the castor bean crop, the Plant Production Department of the School of Agrarian Sciences of Unesp Botucatu (São Paulo State University at Botucatu) began plant science and genetic studies using a population called Guarani. The Guarani cultivar, obtained from producers, was derived from the cultivar IAC Guarani introduced in 1974. Multiplications of the population by producers, without the use of breeding and seed production techniques, as well as without due care so as to avoid crosses with other cultivars and with common castor bean, favored the emergence of genetic variation for important agronomic characteristics. This population constitutes the genetic base of an initial breeding program with a view toward mechanization of the crop and high oil productivity, whether by means of increase of the oil content in the seed or by increase in seed production per hectare.

In the 2004/2005 crop season (October 2004 to May 2005) a total of 60 mother plants were obtained, three types of progenies in each one, making up 60 self-pollinated (AU) progenies, 60 progenies derived from crosses (CR) and 60 open pollinated (PL) progenies.

The self-pollinating progenies were obtained through protection of the inflorescences in anthesis with impermeable paper bags so as to contain the pollen and create the atmosphere of pollen grains inside the bag, favoring fertilization of the female flowers and avoiding contaminations with pollen different from that of the parent (Savy Filho1999).

In the case of progenies obtained by crosses, artificial hybridization was preceded by emasculation of the raceme of the female parent that received the pollen, which was protected with a paper bag of adequate dimensions. For pollination, pollen grains were spread, obtained from a pollen mixture from 100 random plants of the original population on the female flowers, subsequently bagging the raceme (Savy Filho 1999).In open pollination progenies, no measures were taken.

The natural crossing rate was estimated with the use of morphological marker, and for that reason, castor bean lots were installed isolated by a minimum radius of $200 \mathrm{~m}$ among themselves. Each lot was composed of a recessive plant (ss) without aculei and 100 dominant homozygous plants (SS) with aculei. The natural crossing rate was obtained by the ratio between the number of heterozygous plants Ss and the total number of plants per progeny in the recessive plants.

The experiments for evaluation of the progenies were conducted in the municipalities of São Manuel - SP (700 $\mathrm{m}$ altitude, and annual average temperature and rainfall of $20.8^{\circ} \mathrm{C}$ and $1465 \mathrm{~mm}$, respectively)and of Araçatuba - SP (400 $\mathrm{m}$ altitude, annual average temperature and rainfall of $23.8^{\circ} \mathrm{C}$ and $1268 \mathrm{~mm}$, respectively)in the $2005 / 2006$ crop season.

The experiment consisted of three replications and useful plot area of $10 \mathrm{~m}^{2}$, with plants spaced at $1 \mathrm{~m} \mathrm{x} 1 \mathrm{~m}$ in each location and for each type of progeny. For greater local control, the 60 progenies of each type and in each location were arranged in two incomplete blocks, with 30 progenies each, plus three common controls in all the blocks (Guarani Comum, Al Guarany and IAC Guarani).

Each replication consisted of two incomplete blocks, each one with 30 self-pollinating (AU) progenies and three common controls, in addition to two incomplete blocks with 30 progenies of crosses (CR) plus the controls, and finally two incomplete blocks, each one with 30 open pollination (PL) progenies, and the controls.

The trait evaluated was grain yield in $\mathrm{kg} \mathrm{ha}^{-1}$ at $13 \%$ moisture.

The coefficient of inbreeding (F)was calculated in the following manner:

$F_{P L}=s /(2-s) \rightarrow$ open pollination (PL) progenies

It was assumed that the base population is in balance in relation to the reproductive system. 
$F_{A U}=\left(1+F_{P L}\right) / 2 \rightarrow$ self-pollinated progenies $(\mathrm{AU})$

$F_{C R}=0 \rightarrow$ crossed progenies (CR)

Such that:

$F_{P L}=$ mean coefficient of inbreeding in the PL progenies;

$F_{A U}=$ mean coefficient of inbreeding in the AU progenies;

$F_{C R}=$ mean coefficient of inbreeding in the CR progenies;

$S=$ rate of natural self-pollination.

The estimate of inbreeding depression (DE), in percentage in the self-pollinating progenies in relation to the open pollination progenies was obtained using the following expression in each mother plant and in the set of progenies:

$\boldsymbol{D} \boldsymbol{E}_{1}=\left[\left(\bar{Y}_{P L}-\bar{Y}_{A U}\right) / \bar{Y}_{P L}\right] X 100$

Such that:

$\bar{Y}_{P L}=$ mean value of the open pollination progeny;

$\bar{Y}_{A U}=$ mean value of the self-pollinated progeny.

The estimate of depression (DE), in percentage in the self-pollinating progenies in relation to the crossed progenies, for its part, was obtained by the following expression:

$$
\boldsymbol{D} \boldsymbol{E}_{2}=\left[\left(\bar{Y}_{C R}-\bar{Y}_{A U}\right) / \bar{Y}_{C R}\right] X 100
$$

Such that:

$\bar{Y}_{C R}=$ mean value of the crossed progeny;

$\bar{Y}_{A U}=$ mean value of the self-pollinated progeny.

Cockerham and Weir (1984) deduced the components of genetic variation of a trait in populations with partial self-fertilization. One of these components is inbreeding depression, which they represented by $\mathrm{H}$. This quantity is the total depression derived from the contrast between the mean value of the trait in the population under $\mathrm{F}=0$ and the expected mean value under $F=1$. In this study we used the symbol DE to reinforce that this is a partial depression and to avoid confusion with the $\mathrm{H}$ parameter.

As of the results obtained, analysis of variance was carried out of each type of progeny per location, and joint analysis for the two locations due to the occurrence of homogeneity between the mean squares of the residue in each location for the grain yield trait. Preliminary analysis was made only with the data of the controls to evaluate the environmental heterogeneity among incomplete blocks within replications.

\section{RESULTS AND DISCUSSION}

The coefficients of variation of the experiments proved to be within the acceptable limits for agricultural experimentation, ranging from $14.0 \%$ to $16.9 \%$, indicating good experimental precision.

By analyses of variance made with the data of the controls, sufficient homogeneity was detected within the replications, which made it unnecessary to correct the mean values of the progenies based on the mean values of the controls.
In individual analyses per location, significance of the effects of progenies in the three types was observed. In joint analysis there was not significance of the effects of progenies for the three types of pollination, but there was significance of the interaction of progenies $x$ locations in the three types. That showed that the São Manuel and Araçatuba locations have different edaphoclimatic conditions, making the selection of broad adaptation progenies difficult.

Furthermore, another estimate that highlights the magnitude of this effect of the $\mathrm{G} \times \mathrm{E}$ interaction was the absence of phenotypic correlation of the mean values of the progenies between the locations for the three types of progenies (Figure 1), which characterizes the occurrence of complex interaction. These correlations were - $0.133,0.015$ and -0.050 for the CR, PL and AU progenies, respectively. The low correlation indicated that the superior genotypes in one environment will normally not have the same performance in another environment. The magnitude of this interaction is also shown in Table 1, which contains the $20 \%$ best self-pollination progenies in the two locations. It may be observed that only one progeny was coincident.

Table 1. Superior self-pollinating of Ricinus communis L. progenies selected in the two locations under a selection intensity of $20 \%$

\begin{tabular}{cccc}
\hline \multicolumn{2}{c}{ São Manuel } & \multicolumn{2}{c}{ Araçatuba } \\
\hline Progenies & $\begin{array}{c}\text { Yield } \\
\left(\mathrm{kg} \mathrm{ha}^{-1}\right)\end{array}$ & Progenies & $\begin{array}{c}\text { Yield } \\
\left(\mathrm{kg} \mathrm{ha}^{-1}\right)\end{array}$ \\
\hline 53 & 3480.0 & 51 & 4452.7 \\
26 & 3200.3 & 1 & 3664.7 \\
18 & 3196.7 & 8 & 3227.3 \\
45 & 3150.0 & $\mathbf{4 9}$ & $\mathbf{3 1 7 2 . 7}$ \\
$\mathbf{4 9}$ & $\mathbf{3 0 7 8 . 0}$ & 10 & 2824.0 \\
22 & 2830.0 & 6 & 2808.7 \\
44 & 2732.0 & 11 & 2808.0 \\
29 & 2729.0 & 2 & 2732.7 \\
40 & 2646.0 & 55 & 2558.0 \\
56 & 2642.0 & 41 & 2488.6 \\
42 & 2618.0 & 52 & 2435.7 \\
17 & 2512.0 & 34 & 2403.7 \\
\hline
\end{tabular}

In mixed populations, the degree of relationship existing among individuals of maternal families is greater than that expected under allogamy, implying that incorrect estimates of genetic parameters may be obtained if the $F$ rate is considered null. Therefore, consistent determination of the rate of cross fertilization of the populations that one intends to explore becomes essential because that leads to better knowledge of the genetic structure of these populations.

The rates of natural self-pollination were $74.58 \%$ in São Manuel and $67.33 \%$ in Araçatuba, that is, it is expected that 
Cross

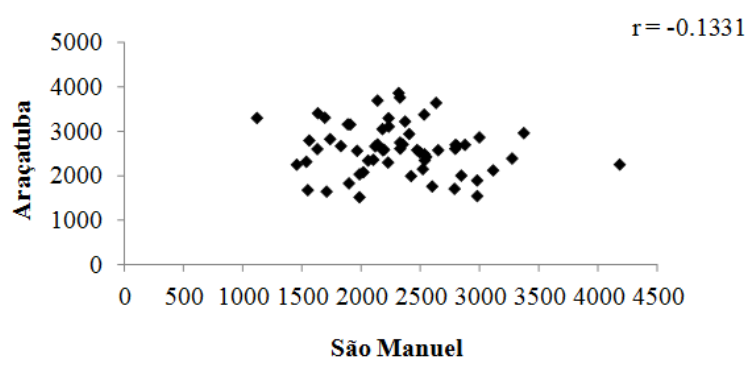

Open Pollination

$r=0.015$
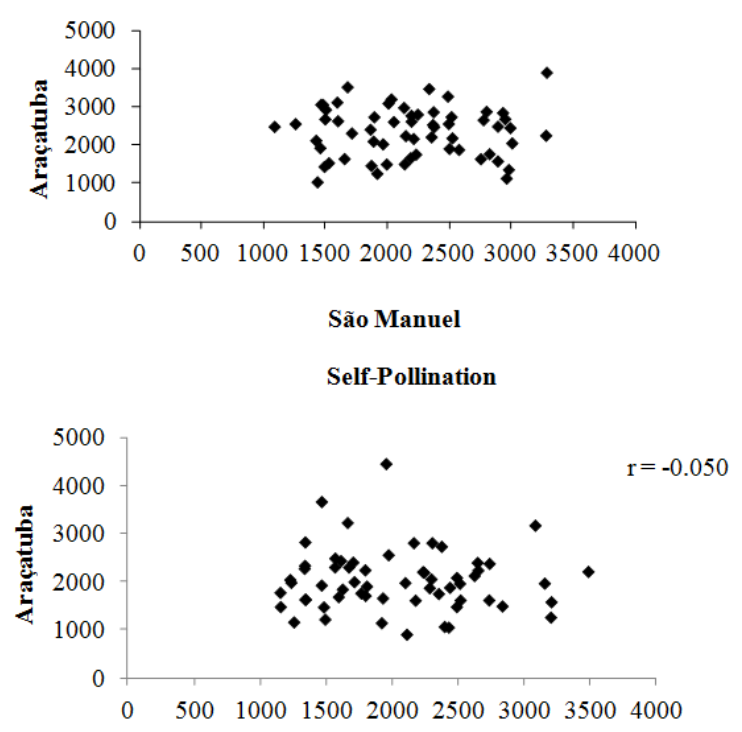

São Manuel

Figure 1. Correlation of grain yield of the three types of progenies of Ricinus communis L. between São Manuel and Araçatuba, SP.

$25.42 \%$ of the plants in São Manuel and $32.67 \%$ of the plants in Araçatuba are not inbred. The differences of the rates of crosses found between the locations of evaluation may be justified by climatic and environmental differences, mainly by different intensities of winds and the presence of insects.

The behavior of grain yield in relation to the coefficient of inbreeding in the three types of progenies for the São Manuel and Araçatuba locations is presented in Figure 2.

The coefficient of inbreeding (F) gives a safe guide to the breeder in regard to the expected degree of homozygosity of a material because it measures the probability of two genes in a given locus being identical by descendancy. In the present study, it is interesting to observe the F values of the open pollination progenies, which were $\mathrm{F}_{\mathrm{PL}}=0.595$ and 0.507 in São Manuel and Araçatuba, respectively. These
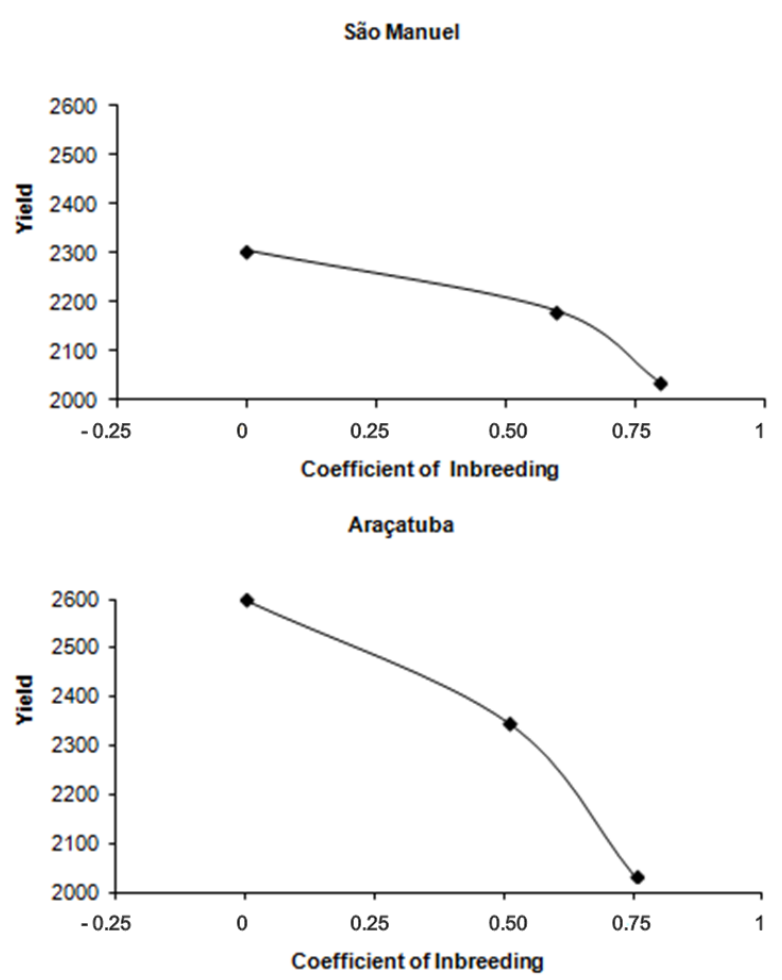

Figure 2. Coefficient of inbreeding $\mathrm{x}$ grain yield $\left(\mathrm{kg} \mathrm{ha}^{-1}\right)$ of Ricinus communis L. progenies in São Manuel and Araçatuba, SP.

values correspond approximately to what is achieved in allogamous species after self-pollination. In this study, after a self-pollination, the $\mathrm{F}$ values increased to $\mathrm{F}_{\mathrm{AU}}=$ 0.797 and $\mathrm{F}_{\mathrm{AU}}=0.753$ in São Manuel and Araçatuba, respectively. For purposes of comparison, these latter values are approximately equivalent to two generations of selfpollination in material with allogamy. The advantage of the mixed species in breeding is evident when the greater goal is obtaining and selection of superior inbred lines with a high degree of homozygosity. For this to be true, it is necessary that the population with the mixed system has a relatively high natural self-pollination rate, as was observed in this study.

It may be observed in Figure 2 that in both locations, the mean grain yield decreased with an increase in the coefficient of inbreeding, as is expected. The interval of variation and the mean value of grain yield $\left(\mathrm{kg} \mathrm{ha}^{-1}\right)$ and the genetic variance $\left(\sigma_{\mathrm{G}}^{2}\right)$ in the three types of progenies in each location are presented in Table 2 . The mean values of the three types of progenies were greater than $2000 \mathrm{~kg}$, a value considered high for castor bean according to Nóbrega et al. (2001). This information is important for it shows that a population with a broad genetic base may be used by small producers in a satisfactory manner. 
Table 2. Interval of variation and mean value of castor bean (Ricinus communis $\mathrm{L}$.) grain yield $\left(\mathrm{kg} \mathrm{ha}^{-1}\right)$ and genetic variances $\left(\sigma_{\mathrm{G}}^{2}\right)$ in the three types of progenies and in the two locations

\begin{tabular}{lccc}
\hline \multirow{2}{*}{ Progenies } & & \multicolumn{2}{c}{ Locations } \\
\cline { 3 - 4 } & & São Manuel & Araçatuba \\
\hline Variation interval & & 1107.0 to 4170.7 & 1517.3 to 3861.7 \\
Crosses & Mean & 2305.4 & 2598.6 \\
$(\mathrm{CR})$ & $\sigma_{\mathrm{G}}^{2}$ & 246878.72 & 284720.50 \\
\hline Variation interval & & 1086.0 to 3282.3 & 1037.3 to 3904.0 \\
Open pollination & Mean & 2184.1 & 2348.9 \\
(PL) & $\sigma_{\mathrm{G}}^{2}$ & 286593.76 & 367300.32 \\
\hline Variation interval & & 1149.0 to 3480.0 & 905.7 to 4452.7 \\
Self-pollination & Mean & 2038.2 & 2034.6 \\
(AU) & $\sigma_{\mathrm{G}}^{2}$ & 292064.64 & 393477.36 \\
\hline
\end{tabular}

It is fitting to comment that in a population like the one studied, whose natural self-pollination rate was $\mathrm{s}=0.7$ in the mean of the two locations, the occurrence of approximately $17 \%$ of plants with a high level of inbreeding is expected ( $F>15 / 16$, Vencovsky et al. 2001). That corresponds to 10 plants in the group of 60 and indicates the relative rapidity in which highly homozygous inbred lines may be extracted in this material.

Genetic variance generally increases as a result of the increase of inbreeding; this may be observed in Table 2, in which the variances of the progenies of self-pollination were greater in both locations, followed by variance of the progenies of open pollination and by those in reference to the progenies of crosses $(F=0)$. The increase of genetic variation among progenies with the increase of inbreeding is an expected phenomenon in allogamous or mixed species. The estimates of $\sigma^{2}{ }_{\mathrm{G}}$ obtained in the AU progenies indicate that the population studied must have good potential for selection of more inbred superior lines. Additional studies are being developed to estimate the components of genetic variation verified, as well as the progress expected from selection.

An advantage for breeding of species that have a mixed reproduction system consists of the fact of natural occurrence, both of crosses and of self-pollination, naturally providing for recombination and partial elimination of genetic load, which makes the selection of segregating individuals possible for traits of interest that present little or no inbreeding depression. In allogamous species, natural recombination occurs, however, the inbreeding depression observed tends to be very high. However, in autogamous species, depression as a result of inbreeding does not occur, but, on the other hand, it is only possible to obtain recombination through artificial pollinations.

Inbreeding depression presented pronounced variation, there being mother plants in which it was negative; i.e., the self-pollination progenies produced more in relation to the progenies of open pollination and crosses. Most of the mother plants, however, showed positive inbreeding depression (Table 3).

Bertini et al. (2001) found negative inbreeding depression in cotton plants for the traits of cottonseed and fiber production, a species that has a mixed reproductive system. Ferreira et al. 2002, studying inbreeding depression in another species of mixed reproduction system, watermelon, observed that, in spite of mean depression having been low, there was wide variation in the amplitude of the depression. In corn, an allogamous species, depression in relation to grain yield showed a variation from $27.6 \%$ to $59.13 \%$, according to Amorimand Souza (2005). These estimates, with rare exceptions, are near or greater than those reported for the maize crop.

Table 3. Interval of variation of inbreeding depression (DE) in \%, standard deviation and number of progenies with positive and negative DE among the open pollination and self-pollinated progenies and crossed and self-pollinated progenies of Ricinus communis L., in the two locations

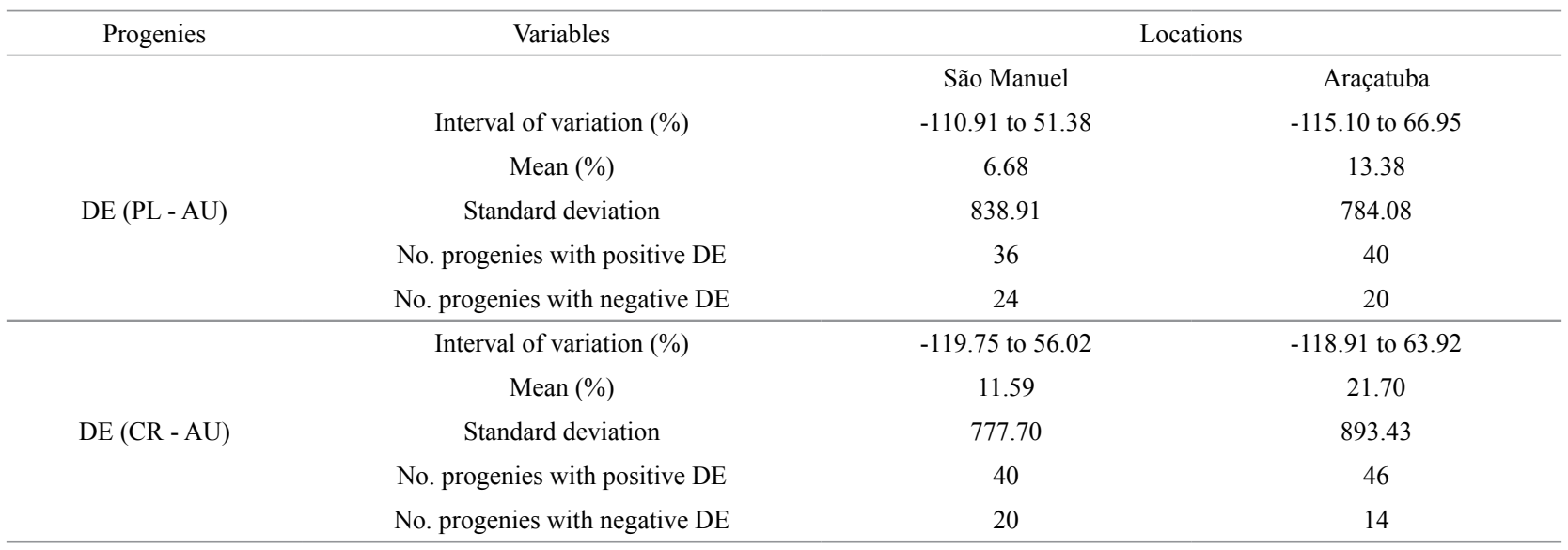


Table 4. Progenies with yield greater than the mean of the Ricinus communis L. progenies artificially crossed and with negative or low inbreeding depression

\begin{tabular}{cccc}
\hline & \multicolumn{3}{c}{ São Manuel } \\
\cline { 2 - 4 } Progenies & DE (PL - AU)* & DE (CR - AU) * & $\begin{array}{c}\text { Mean values of } \\
\text { progenies CR* }\end{array}$ \\
\hline 26 & -703.3 & -681.3 & 2519.0 \\
42 & -728.0 & -301.3 & 2316.7 \\
43 & -1338.0 & 214.3 & 2638.3 \\
44 & -1256.0 & 132.3 & 2864.3 \\
45 & -786.0 & -668.7 & 2481.3 \\
\hline
\end{tabular}

\begin{tabular}{cccc}
\hline \multicolumn{3}{c}{ Mean yield of crossed progenies } & 2305.4 \\
\hline \multirow{3}{*}{ Progenies } & \multicolumn{3}{c}{ Araçatuba } \\
\cline { 2 - 4 } & DE (PL - AU)* & DE (CR - AU)* & $\begin{array}{c}\text { Mean values of } \\
\text { progenies CR* }\end{array}$ \\
\hline 1 & -1171.0 & -996.0 & 2668.7 \\
52 & -1303.3 & 389.6 & 2825.3 \\
55 & -1051.7 & 402.5 & 2960.5 \\
\hline
\end{tabular}

Mean yield of crossed progenies

2598.6

* Values in $\mathrm{kg} \mathrm{ha}^{-1}$

Inbreeding depression showed pronounced variation in the two locations (Table 3). On average, it was low, but verifying the $\mathrm{DE}$ values, both in the comparison between $\mathrm{PL}$ and $\mathrm{AU}$, as well as between $\mathrm{CR}$ and $\mathrm{AU}$, progenies were observed in which there was a numerical increase in grain yield after self-pollination. Such result must arise from parents with high homozygosity and carriers of favorable alleles for the trait. In addition to gene dominance, epistatic effects may not be excluded (Vencovsky 2001). The respective self-pollination progenies are candidates for serving as a source of pure lines, with a view toward obtaining hybrids.

In obtaining synthetic varieties in mixed species, the reasoning is broader than in allogamous varieties. In the latter, the general and specific combination capacity matter. In mixed species, maintenance of a synthetic variety involves crosses and natural self-pollination. The ideal is thus to select superior inbred lines derived from parents that also have good combination capacity. Table 4 gives a list of progenies with negative or low DE whose mother plants, when crossed, generated progenies with yield above the respective general average. The number of progenies with these two properties was relatively low. Greater success may be expected evaluating a greater number of progenies. Negative values of DE when estimated as based on PL progenies were similar in comparison to the values of DE based on CR progenies. This is important in the search for homozygous lines or synthetic varieties because, in PL progenies, it is not necessary to spend time and resources to carry out artificial crosses.

\section{CONCLUSIONS}

1 - Given the predominance of the G x E interaction, the small correlation and small coincidence of progenies selected between locations, the difficulty of selection of progenies of wide adaptation becomes evident. Evaluation of a greater number of progenies should increase the possibility of obtaining productive progenies in both locations.

2 - In spite of the mean inbreeding depression having been low, wide variation was observed, from high positive values to high negative values. This shows the possibility of carrying out selection among the progenies so as to give priority to those that present high mean values in crosses, as well as negligible or negative inbreeding depression. To obtain a sufficient number of progenies of this type, it would also be necessary to evaluate a greater number of progenies.

3 - The conclusions of item (2) indicate the possibility of selecting progenies with a view toward obtaining synthetic varieties. Practicing prior recurrent selection in the population should increase the occurrence of more homozygous mother plants with good performance in crosses and negligible inbreeding depression. This should be possible from the wide genetic variation detected. Such a fact will favor obtaining superior synthetic varieties.

\section{Depressão endogâmica em progênies de mamona (Ricinus communis L.)}

Resumo - O objetivo do trabalho foi investigar a depressão endogâmica (DE) na mamoneira, espécie de reprodução sexuada mista. De uma população derivada da cultivar Guarani, amostraram-se 60 plantas-mãe. De cada uma foram obtidos três tipos de progênies: de autofecundação (AU), de cruzamentos obrigatórios (CR) e de polinização livre (PL). A produtividade de grãos das progênies for avaliada por meio de experimentos em blocos incompletos em dois locais. Houve forte interação de progênies $x$ locais o que levou a obter estimativas dentro de cada local. Verificou-se ampla variação na depressão endogâmica, com médias de 6,7\% e 13,4\%, comparando-se as progênies AU com as PL. Verificou-se que a população tem alto potencial para selecionar linhagens promissoras. Foi baixa a freqüência de plantas-mãe gerando progênies com alta capacidade geral de combinação e baixa depressão endogâmica, simultaneamente. Seleção recorrente aumentará a ocorrência de genitoras associando essas duas propriedades, necessárias para obtenção de variedades sintéticas superiores.

Palavras-chave: Mamoneira, depressão endogâmica, variedades sintéticas, interação Gx E. 


\section{REFERENCES}

Amorim EP and Souza JC (2005) Híbridos de milho inter e intrapopulacionais obtidos a partir de populações $\mathrm{S}_{0}$ de híbridos simples comerciais. Bragantia64: 561-567.

Bertini CHCM, Silva FP, Nunes RP and Santos JHR (2001) Ação gênica, heterose e depressão endogâmica de caracteres de produção em linhagens mutantes de algodoeiro herbáceo. Pesquisa Agropecuária Brasileira 36: 941-948.

Cockerham CC and Weir BS (1984) Covariances of relatives stemming from a population undergoing mixed self and random mating. Biometrics 40: 157-164.

Costa MN, Pereira WE, Bruno RLA, Freire EC, Nóbrega MBM, Milani $\mathrm{M}$ and Oliveira AP (2006) Divergência genética entre acessos e cultivares de mamoneira por meio de estatística multivariada. Pesquisa Agropecuária Brasileira 41: 1617-1622.

Ferreira MAJ, Queiróz MA, Vencovsky R, Braz LT, Vieira MLC and Borges RME (2002) Sexual expression and mating system in watermelon: implications for breeding programs. Crop Breeding and Applied Biotechnology 2: 39-48.

Freire EC, Lima EF and Andrade FP (2001) Melhoramento genético. In Azevedo DMP and Lima EF (eds.) O agronegócio da mamona no Brasil. Embrapa Algodão, Brasília, p. 230-256.

Godoy AR, Oviedo VRS and Cardoso AII (2005) Análise endogâmica de uma população de pepino caipira. Horticultura Brasileira 23: 785-788.
Govindan A, Suriyaumar M, Kumar VVet al (1999) TMVCH1 - the first castor hybrid for Tamilnadu. Tamilnadu Agricultural University. The Madras Agricultural Journal 86: 94-96.

Manivel P, Hussain HSJ, Dharmalingam V and Pandian IS (1999) Heterosis for yield and its components over environments in castor (Ricinus communis L.). The Madras Agricultural Journal 86: 65-68.

Nóbrega MBM, Andrade FP, Santos JW and Leite EJ (2001) Germoplasma. In Azevedo DMP and Lima EF (eds.) O agronegócio da mamona no Brasil. Embrapa Algodão, Brasília, p. 257-281.

Savy Filho A (1999) Hibridação em Mamona. In Borém A. (ed.) Hibridação artificial de plantas. Editora UFV, Viçosa, 331-342.

Savy Filho A (2005) Mamona: tecnologia agrícola. Emopi, Campinas, $105 p$.

Scapim CA, Braccini AL, Pinto RJB, Amaral Júnior AT, Rodovalho MA, Silva RM and MoterleLM (2006) Componentes genéticos de médias e depressão por endogamia em populações de milho-pipoca Ciência Rural 36: 36-41.

Simom GA, Scapim CA, Pacheco CAP, Pinto RJB, Braccini AD and Tonet A (2004) Depressão por endogamia em populações de milho-pipoca. Bragantia 63: 55-62.

Vencovsky R, Pereira MA, Crisóstomo JR and Ferreira MAJF (2001) Genética e melhoramento de populações mistas. In Nass LL, Valois ACC, Melo IS and Inglis MCV (eds.) Recursos genéticos e melhoramento - plantas. Fundação MT, Rondonópolis, p. 231-282. 
IJ Oliveiraet al. 